\title{
THE STATE AS A GUARANTOR OF THE PROTECTION OF THE RIGHTS OF INDIVIDUALS AND LEGAL ENTITIES IN THE CONDITIONS OF CORONAVIRUS CRISIS OF 2020
}

DOI: 10.36740/WLek202012209

\author{
Oleksandra Rudnyeva, Olena Prykhodko \\ SCIENTIFIC RESEARCH INSTITUTE OF STATE BUILDING AND LOCAL GOVERNMENT OF NATIONAL ACADEMY OF LAW SCIENCES OF UKRAINE, KHARKIV, UKRAINE
}

\begin{abstract}
The aim of the article is to stimulate discussions about the necessity to improve the legal regulations that guarantee a proper public health policy, as well as to determine the balance between the level of restrictions that may be imposed by State in order to protect both, the public interest of health and the economic development.

Materials and methods: National legislation of Ukraine, United Kingdom and France on public health and health policy, case law of these countries, including high court decisions were used for dialectical, comparative, synthetic and systemic analyses.

Conclusions: As the legality of government officials' actions principle is a fundamental constitutional principle in most European countries, states must establish such legal provisions to avoid short-term and long-term conflicts when the rights of individuals and legal entities are being restricted.

At the legislative level, it is necessary to adopt transparent rules to attract private funding to the health sector. Development of the e-health and telemedicine systems could be boosted through the use of public-private partnership tools.
\end{abstract}

KEY WORDS: public-private partnership, public health, e-Health, telemedicine

Wiad Lek. 2020;73(12 p. II):2752-2757

\section{INTRODUCTION}

In the 21st century, public health care has become a primary responsibility of the state. This statement is included in all national constitutions of European countries and universally binding international documents. International legal standards have been developed, being under custody of not only the World Health Organization (WHO) and its strategic governmental and non-governmental partners, such as International Red Cross, but also other institutions and organizations on the regional, national and local levels.

However, the system that was established in the second half of the 20th century by the efforts of many governments, experts, and enthusiasts, and that deemed to be one of the most successful social projects of mankind, is now coming under criticism from various sides in the 21st century.

There are many reasons for this and for the most part they are related to new infectious diseases emerging and spreading beyond their usual endemic regions such as Africa and Asia.

At the national level, most countries appeared not to be ready for the

practical security of people's constitutional guarantees of health protection in a situation that in the expert community is increasingly referred to as a 'coronacrisis'[1].

Legatum Institute, the UK based think tank announced that 'compared to the situation where the Covid-19 pandemic had not hit the country, 440,000 more people were in poverty in Summer 2020 and 690,000 more in Winter 2020'. By Spring 2021 nearly 15,5 mln people in the UK will live in poverty. The original analysis uses the Social Metrics Commission's approach to poverty measurement and the assessment of the likely course of poverty since the start of the crisis, the protective impact of Government action that has already been taken, and choices that still need to be made. [2].

Among the many reasons of a political, social, economic and institutional nature, special focus should be given to the legal assessment of the states actions aimed at the introduction of quarantine measures and their correct implementation, since they are often and sometimes considerably associated with the restriction of basic rights and freedoms of citizens. The balance between public and private interests in such situations can be achieved only partially, as these are not always synchronized with time and value.

\section{THE AIM}

The aim of the article is to stimulate discussion about the necessity to improve the role of the state and legal regulations to guarantee proper public health policy, and determine the balance between the amount of restrictions that may be used by the public officials in order to protect public interest for a healthy life and tools for economic development. 
This article also describes how the crisis in the health care system in Ukraine influenced the development of electronic health care system (e-Health system) and telemedicine.

\section{MATERIALS AND METHODS}

This study was conducted in 2020 and is based on the national legislation of Ukraine, regulatory acts in the field of public health, the practice of the Constitutional Court of Ukraine, legislation of the selected European countries such as the UK and France, case law of these three countries. Dialectical, comparative, synthetic and system analyses research methods were used, including for interpretation purposes.

\section{REVIEW AND DISCUSSION}

The global coronavirus pandemic has become a challenge for national health care systems worldwide. Many countries searched for their own response to this challenge, and actions of the governments were not always adequate and effective.

The effectiveness of the measures to ensure the protection of human health security with the Law and state measures can be understood through the analysis of three relatively independent but closely related issues:

1) the establishment and application of proper legal regulation in public health;

2) the establishment of proper cooperation between the state and private business to ensure that all restrictions will not affect human life or health and, at the same time, will minimize the damage to the economic activity of companies to a possible level ;

3) the proper regulation of circumstances surrounding administrative disorder, to ensure the right of the public officials and law enforcement officers to interfere into private business and private territory even if it seems to pose a real damage to his/her personal freedoms and economical interests.

It is important to find out what kind of measures can be considered and the most effective answer to the situation.

In Ukraine, the state's response to the coronavirus epidemic was the introduction of quarantine, a number of restrictions and bans. Thus, on March 11,2020, the Cabinet of Ministers of Ukraine adopted Decree No. 211 "On the Prevention of the Spread of COVID-19 Coronavirus on the territory of Ukraine". This Decree, in particular, forbade students from visiting educational institutions, and banned all mass gatherings with more than 200 participants, except for events necessary to ensure the operation of public authorities and local governments from March 12 to April 3, 2020 in the whole territory of Ukraine. Sports events could only be held without the participation of the public (fans) [3].

However, already on March 17, the list of restrictions provided by the governmental Degree on the quarantine measures was significantly expanded. The most controversial and important restrictions were the ones for businesses whose activities involve reception of visitors, including catering businesses (restaurants, cafes, etc.), shopping and entertainment centers, other entertainment establishments, fitness centers, cultural institutions, trade and consumer service organizations. In addition, the Decree significantly restricted the freedom of movement of citizens. This included a ban on transportation of passengers by road in suburban and interurban motor service, the carriage of more than 10 passengers at a time in one vehicle in urban electric transport and in buses. Decree No. 211 also banned transportation of passengers by subways in the cities of Kyiv, Kharkiv and Dnipro, as well as the transportation of passengers by any routes of rail transport inside the country.

During 2020, the Decree of the Cabinet of Ministers of Ukraine «On Prevention of the Spread of COVID-19 Coronavirus on the territory of Ukraine» has been amended 17 times.

On May 20, 2020 the Cabinet of Ministers of Ukraine adopted another special Decree No. 392 «On the establishment of quarantine to prevent the spreading of COVID-19 acute respiratory illness caused by the SARS-CoV- 2 coronavirus and the mitigation of anti-epidemic measures in Ukraine.» This Decree clarified the list of prohibitions and changed the model of quarantine measures (from allUkrainian to adaptive depending on certain indicators) [4].

The epidemic also led to some changes in Ukrainian legislation. Thus, special provisions were introduced into the Labor Code of Ukraine, the Code of Administrative Offenses, the Tax Code of Ukraine, the Law of Ukraine «On Holidays», etc.

It should be noted that the introduction of quarantine on the territory of Ukraine by the Cabinet of Ministers, namely certain significant restrictions on human rights and freedoms introduced by the quarantine, caused discussions in the society and in the experts level. The key points of discussion were the proportionality of the restrictions in regard to the real threats, as well as the Government's authority to introduce prohibitions such as travel bans or restrictions on businesses without amending the law or declaring a state of emergency by the Parliament.

The issue of proportionality of the restrictions became a pressing challenge not only in Ukraine. It was reviewed by many European courts. So, for example, in the decision of the Council of the State of France (Conseild'Etat) of September 06, 2020, in the case involving the issue of liability for not wearing masks, it was noted that in the context of the rule of law, freedom should remain the rule and police restrictions the exception. It follows therefor, that measures, restricting rights and freedoms are lawful only if they meet the three requirements of the principle of proportionality: necessity, adequacy and proportionality. Thus, this measure must be applied first and foremost to prevent a risk to public order, such as a health risk. In the absence of such a risk this measure shall be deemed illegal. Only in such a case can this measure achieve the intended goal, otherwise it will be either inadequate or inappropriate [5]

Based on these arguments, the Council of State partially reversed the interim orders of theadministrative courts of Lyon and Strasbourg, ordering the prefects of Rhône and Bas-Rhinto 
review as soon as possible - under penalty of suspension - their decrees imposing the wearing of a protective mask for people aged 11 or over in open public places in the cities of Lyon and Villeurbanne, on the one hand, and in municipalities with more than 10,000 inhabitants in the Eurometropolis of Strasbourg, somewhere else. This half-hearted decision has not prevented the proliferation, since then, of orders of the same type on French territory, although it seems to proceed from a very timid application of the requirement of proportionality.

In this regard, it should be noted that Ukrainian judges also drew attention to these issues. The Supreme Court filed to the Constitutional Court of Ukraine a petition to declare certain provisions of the Decree of the Cabinet of Ministers of Ukraine «On the establishment of quarantine to prevent spreading of COVID-19 acute respiratory illness caused by the SARS-CoV-2 coronavirus and the mitigation of anti-epidemic measures in Ukraine» and some other bylaws as unconstitutional.

The Constitutional Court of Ukraine made reference to Article 64 of the Constitution of Ukraine, according to which the constitutional human rights and freedoms shall not be restricted, except in cases provided by the Constitution of Ukraine; in the state of emergency, including state of defense, certain restrictions on rights and freedoms may be established, with indication of the term of these restrictions; however, the rights and freedoms envisaged in Articles 24, $25,27,28,29,40,47,51,52,55,56,57,58,59,60,61,62,63$ of the Constitution of Ukraine shall not be restricted.

The Constitutional Court of Ukraine also stated that the restriction of constitutional human rights and freedoms is possible in cases specified by the Constitution of Ukraine. Such restrictions shall only be established by law - by an act adopted by the Verkhovna Rada of Ukraine as the onlylegislative body in Ukraine. Establishing such restrictions with a bylaw contradicts Articles 1, 3, 6, 8, 19, 64 of the Constitution of Ukraine [6].

The debate over the lawfulness of quarantine restrictions is relevant to other countries as well.Given that the principle of legality of actions of government officials is a basic constitutional principle in most European countries, states are obliged to establish such provisions of law so that short-term and long-term conflicts do not arise when applying procedures related to restriction of rights of individuals and legal entities.

In France there is a general principle of legality (principe de légalité) according to which the powers of the French administration are subordinate to the law. This principle has been affirmed in jurisprudence of the Conseil d'Etat (Highest French Court in charge of the administration both before and after the 1958 version of the French Constitution)Prosper Weil says that"all the action of the administrative bodies is governed by the principle of legality. The regulation may be part of the character of the law - by its general and impersonal character - but the case law decides that, emanating from the government, it is an administrative act subject to the principle of legality." [7]

For lawyers and judges the issue about justification of risks and their comprehensive relevance to the scientific data is important when the violation of restrictions of the rights and freedoms is under review.
Professor Jeff King from the University College London and a Legal Adviser to the House of Lords Constitution Committee says:The Health Protection (Coronavirus, Restrictions) (England) Regulations 2020 (Reg 6) and the Health Protection (Coronavirus Restrictions) (Wales) Regulations 2020 (Reg 8) both provide in identical wording that 'During the emergency period, no person may leave the place where they are living without reasonable excuse.' Both also enumerate thirteen exceptions ('reasonable excuses') to the rule. These are the restrictions widely referred to as the 'lockdown.' There is a question at the moment about whether they are so invasive as to be unlawful [8].

The recently adopted Coronavirus Act 2020 does not confer new powers on the UK and Welsh ministers to impose a lockdown on the people of England and Wales. It does confer such powers on Northern Ireland (specifically, the Northern Ireland Department of Health) in Schedule 18; and on Scottish ministers inSchedule 19. Neither Northern Ireland nor Scotland had them previously. The scheme in those two schedules is roughly - and in the case of Northern Ireland almost verbatim - based on the powers accorded to UK and Welsh ministers under the Public Health (Control of Disease) Act 1984. It is there that the source of the powers both now and into the future are to be located in respect of any lockdown. If the present lockdown is found to be outwith the 1984 Act, it would follow that no lockdown is presently permissible anywhere in the country.

In the lockdown regulations cited above, the UK Government has clarified that it is acting under section $45 \mathrm{C}$ :

- $s .45 C(1)$ : 'The appropriate Minister may by regulations make provision for the purpose of preventing, protecting against, controlling or providing a public health response to the incidence or spread of infection or contamination in England and Wales (whether from risks originating there or elsewhere).'

- s.45C(2): 'The power in subsection (1) may be exercised-

(a) in relation to infection or contamination generally or in relation to particular forms of infection or contamination, and

(b) so as to make provision of a general nature, to make contingent provision or to make specific provision in response to a particular set of circumstances.'

- $\quad$ s.45C(3)(c): 'Regulations under subsection (1) may in particular include provision... imposing or enabling the imposition of restrictions or requirements on or in relation to persons, things or premises in the event of, or in response to, a threat to public health.'

- $s .45 \mathrm{C}(4)(\mathrm{d})$ : 'The restrictions or requirements mentioned in subsection (3)(c) include in particular...a special restriction or requirement.' [9]

Jeff King is a strong supporter of restrictions and limitation,and he is referring to the opposite minds which are widespread among the UK lawyers.

As the jurist and peer, Lord Anderson, has put the challenge on his blog, '[f] or such a remarkable limitation of personal freedom to be contemplated by statute, one would have expected to find clear words in section $45 \mathrm{G}(2)$ : 
something like "that $\mathrm{P}$ be required not to leave the place where $\mathrm{P}$ is living, save for specified purposes." That might seem apiece with the idea behind the principle of legality and many other public law cases which are apt to deny that general rather than specific words can permit serious infringements of personal liberty. Relatedly, was it the gist of the Act to deal with something much more limited than a health scare that precipitates a nation-wide lockdown? [8]

In our opinion, and as also reflected in the decision of the Constitutional Court of Ukraine, consideration of the problem of the efficiency and adequacy of the state response to the spread of COVID-19 should be based on the provisions of Article 19 of the Constitution of Ukraine, according to which governmental authorities and local governments and their officials shall only act on the basis, within the powers and in the manner prescribed by the Constitution and laws of Ukraine. Thus, public authorities in Ukraine do not possess as much discretion compared to the respective organs in some other countries, but must explicitly act within the adopted legislation. In view of the above decision of the Constitutional Court, it becomes obvious that this constitutional principle was violated by the highest executive body, as a result of which significant interference with human rights and freedoms was committed and significant losses were caused to business entities. Without assessing the issue of reasonability of restrictions from the medical point of view, it can be argued that from the legal point of view, actions and decisions of the authorities of Ukraine did not meet the requirements of the fundamental law.

Quarantine has had a significant negative impact on business. Some sectors of the economy have experienced a decline, and large numbers of small and medium-sized businesses have been forced to lay off large numbers of workers or completely shut down. We agree with the authors of the scientific report «Ukraine after the coronavirus crisis - the way to recovery» stating that the restrictions had a significant negative impact on the country economy, causing some side effects of the «treatment» of the country from the spread of coronavirus [10].

Next, we will discuss whether the quarantine measures implemented in Ukraine and the crisis caused by the spread of COVID-19 had any positive consequences for the health care system in Ukraine. In this part, two issues should be reviewed: the development of the electronic health care system (eHealth system) and the introduction of telemedicine in the healthcare practice during quarantine.

Article 2 of the Law of Ukraine «On State Financial Guarantees of Medical Care» establishes the definition of the term electronic health care system, which is an information and telecommunications system that automates the accounting of medical services and management of medical information through the creation, post, publication and exchange of information, data and documents in electronic form, which includes a central database and electronic health information systems, with automatic exchange of information, data and documents between these through an open application programming interface (API).
The law states that the access to the patient's data in the electronic health care system is only possible with the consent of the said patient (or his legal representative) provided in writing or in a form that allows to make a conclusion about the consent [11].

The legal framework for the electronic health care system was laid several years before the coronavirus pandemic. The Procedure for operation of the electronic health care system was approved by the Decree of the Cabinet of Ministers of Ukraine No. 411 of April 25, 2018. This legal act was made to define the mechanism of the electronic health care system's functioning and its components, user registration, entry and exchange of information and documents within the electronic health care system. At the same time, the Government established that from the date when this Decree enters into force, the functionality of the electronic health care system shall become gradually introduced to implement state guarantees of medical care at the level of primary health care [12].

Therefore, as can be seen from the above-mentioned legal norms, the electronic health care system had to be introduced step by step. Its full launch involved a large amount of regulatory and technical activities. Thus, the Cabinet of Ministers of Ukraine assigned a number of tasks to the Ministry of Health of Ukraine, including:

developing a complete design and regulations necessary for the functioning of the electronic health care system in the framework of the state medical care guarantees, at the level of secondary (specialized), tertiary (highly specialized) and other types of medical care, in accordance with the implementation stages of the public healthcare's financial guarantees;

ensuring the development, operation, and financing of the central database of the electronic health care system and transfer of property rights to the central database software to the National Health Service by January 1, 2019;

including to the central database of the electronic health care system of the data contained in the electronic system of medical information exchange, created on the basis of the Concept of Healthcare Financing Reform, approved by the Order of the Cabinet of Ministers of Ukraine No. 1013 of November 30, 2016, and the action plan for implementation of the Concept of Healthcare Financing Reform for the period until 2020, approved by the Order of the Cabinet of Ministers of Ukraine No. 821 of November 15, 2017, as well as verification of relevant data; creating a comprehensive information security system complying with the central database electronic health care system.

Therefore, practical implementation of the electronic healthcare system established by the law provided for a significant amount of further work at the level of the relevant ministry. This work involved both rule-making activities, detailed elaboration of regulation, as well as solving a large number of technical issues.

As stated by R.V. Vlasenko, the electronic health care system (e-Health) is based on creation and maintenance of a number of electronic registries. However, at this time, 
creation and filling of such registries is performed slowly and inconsistently, which causes technical and organizational problems in the functioning of the eHealth system, negative perception of the health care reform in general by patients and health professionals and in general reduces the availability of health services to end users. This situation resulted from a number of systemic problems, first of all:

- gaps in the legislation governing the establishment of health registries;

- unpreparedness of the supporting infrastructure, including incompatibility of the existing health information systems and lack of computer and network equipment in health care facilities, in particular due to lack of funding for the process of digitization of medical data and creation of infrastructure for the provision of high-quality medical services [13].

According to the researcher, despite the National Health Service of Ukraine statements about nearly $85 \%$ readiness of Ukrainian medical institutions for autonomization, the Ministry of Statistics shows that only $45 \%$ of medical institutions have an Internet connection, and the overall level of computerization of medical institutions is $42.7 \%$. Without launching the main components of eHealth (including electronic medical registries), the effectiveness of the latest innovations in the electronic health care system is significantly reduced, and in some cases even creates new obstacles. Therefore, legislation of Ukraine urges changes in terms of building a consistent policy of implementation and filling of electronic medical registries with allocation of appropriate funding. First of all, it concerns the issue of creating conditions (including material ones) for the functioning of the nosology registers for diseases that cause the highest mortality and disability, and orphan diseases. [13].

Indeed, further completion of electronic medical data registries requires significant investment from the state. And this could be the subject of the active use of public-private partnership. However, despite the fact that the healthcare system in Ukraine is under extreme strain during quarantine, the Parliament has not yet adopted any laws that would create the conditions for effective and transparent involvement of private capital in the healthcare sector.

It should be noted that the coronavirus pandemic became a boon for telemedicine in Ukraine.

The main legislative act regulating the development of telemedicine in Ukraine is the Order of the Ministry of Health No. 681 «On approval of regulations on the use of telemedicine in health care» of October 19, 2015.

This normative act defines that telemedicine is a set of actions, technologies and measures implemented in the provision of medical care using remote means of communication in the form of electronic messaging.

Primary objectives of telemedicine include:

providing medical care to the patient when the distance is a critical factor in its provision;

maintaining medical secrecy, confidentiality, and integrity of medical information about the patient's health; creating a single medical space; promoting the quality of care and optimizing the processes of organization and management of health care; developing systemic approaches to the introduction and development of telemedicine in the health care system [14].

Telemedicine is a way to provide help to patients at a distance and in those conditions when they are not able to leave their homes. And hence, the quarantine, introduced in many countries around theworld to prevent the spread of coronavirus disease (COVID-19), further accelerates the pace of development of remote medical care. Thanks to telemedicine, consultations of the best doctors, including highly-specialized physicians, become available in the most remote settlements and distant countryside.

Therefore, while before the pandemic telemedicine was an optional and non-compulsory service for many doctors, it has now become an essential part of providing health services to the population.

The active use of telemedicine technologies in the fight against coronavirus has contributed to its extremely rapid development. In this aspect, it can be noted that free telemedicine services have become available not only to doctors but also to patients. In addition, the area of services offered by medical mobile applications has significantly expanded. The field of telemedicine peer counselling for doctors has also expanded. Now, active peer counselling is available not only for primary-, secondary- and tertiary-level physicians, but also for doctors of specific specialties.

\section{CONCLUSIONS}

Most countries are not ready to practically ensure constitutional guarantees of human rights to health care in the context of the spread of COVID-19 on the one hand, and, a balance between restrictions of rights and freedoms, and, economical and social interests of humans and private businesses on the other. Restrictions on the exercise of powers by public authorities, the introduction of quarantine-related subordinate legislation in Ukraine actually violated the constitutional rights of its citizens. Development of the eHealth system and further completion of electronic medical registries, which requires significant financial investment from the state, could be boosted through the use of public-private partnership tools. At the same time, the coronavirus pandemic has become a significant impetus to the development of telemedicine in Ukraine, which contributed to the more rapid provision of medical services to all target groups.

\section{REFERENCES}

1. Culture Lab Europe: Spaces for Solidarity. European Creative Business Network, 2020. Available from: http://ecbnetwork.eu/ccis-coronacrisisupdate-71-culture-lab-europe-spaces-for-solidarity [reviewed 2020.08.12]

2. Poverty during the Covid-19 crisis. Legatum Institute, 2020. Available from: https://li.com/reports/poverty-during-the-covid-19-crisis/ [reviewed 2020.08.20] 
3. Postanova Kabinetu Ministriv Ukrainy vid 11.03.2020 № 211. Pro zapobihannia poshyrenniu na terytorii Ukrainy hostroi respiratornoi khvoroby COVID-19, sprychynenoi koronavirusom SARS-CoV-2 [Decree of the Cabinet of Ministers of Ukraine dated 11.03.2020 № 211. On prevention of the spread of acute respiratory disease COVID-19 caused by coronavirus SARS-CoV-2 on the territory of Ukraine]. Available from: https://zakon.rada.gov.ua/laws/show/211-2020-\%D0\%BF/ ed20200311\#Text [reviewed 2020.08.20] (Ua).

4. Postanova Kabinetu Ministriv Ukrainy vid 20.05.2020 № 392. Pro vstanovlennia karantynu z metoiu zapobihannia poshyrenniu na terytorii Ukrainy hostroi respiratornoi khvoroby COVID-19, sprychynenoi koronavirusom SARS-CoV-2 [Decree of the Cabinet of Ministers of Ukraine dated 20.05.2020 № 392. On establishment of quarantine for the purpose of prevention of the spread of acute respiratory disease COVID-19 caused by coronavirus SARS-CoV-2 on the territory of Ukraine]. Available from: https://www.kmu.gov.ua/npas/provstanovlennya-karantinu-z-metoyu-zapobigannya-poshirennyuna-teritoriyi-ukrayini-gostroyi-respiratornoyi-hvorobi-covid-19sprichinenoyi-koronavirusom-sars-cov-i200520-392 [reviewed 2020.08.20] (Ua).

5. Covid : les mesuresrestrictives de libertérésistent-elles au test de proportionnalité? 2020. Available from: https://www.dalloz-actualite. $\mathrm{fr} /$ node/covid-mesures-restrictives-de-liberte-resistent-elles-au-testde-proportionnalite\#.X8VDIxP0124 [reviewed 2020.08.20] (Ua).

6. Rishennia Konstytutsiinoho Sudu Ukrainy № 10-p/2020 vid 28.08.2020 [Decision of the Constitutional Court of Ukraine № 10p/2020 dated 28.08.2020]. Available from: http://www.ccu.gov.ua/ dokument/10-r2020 [reviewed 2020.09.10] (Ua).

7. ProsperWeil, Dominique Pouyaud, Le Droit Administratif, 2017:77-87,4.

8. Jeff King: The Lockdown is Lawful, 2020. Available from: https:// ukconstitutionallaw.org/2020/04/01/jeff-king-the-lockdown-islawful/ [reviewed 2020.08.20].

9. Public Health (Control of Disease) Act 1984. Available from: https:// www.legislation.gov.uk/ukpga/1984/22/part/2A/crossheading/ power-to-make-regulations [reviewed 2020.08.20].

10. Ukraina pislia korona kryzy - shliakh oduzhannia: naukova dopovid [Ukraine after the corona crisis - the path to recovery: a scientific report]. The National Institute for Strategic Studies. Kyiv, 2020. 304 p. (Ua).

11. Pro derzhavni finansovi harantii medychnoho obsluhovuvannia naselennia: Zakon Ukrainy vid 19.10.2017 № 2168-VIII [On State Financial Guarantees of Medical Care : Law of Ukraine dated 19.10.2017 № 2168-VIII]. Available from: https://zakon.rada.gov.ua/laws/ show/2168-19\#Text [reviewed 2020.08.20] (Ua).
12. Postanova Kabinetu Ministriv Ukrainy vid 25.04.2018 № 411. Deiaki pytannia elektronnoi systemy okhorony zdorovia [Decree of the Cabinet of Ministers of Ukraine dated 25.04.2018 № 411. Some issues of the electronic health care system]. Available from: https://zakon.rada.gov. ua/laws/show/411-2018-\%D0\%BF\#Text [reviewed 2020.08.20] (Ua).

13. Vlasenko R. V. Shchodo napriamiv vdoskonalennia elektronnykh reiestriv systemy okhorony zdorovia Ukrainy [Regarding the areas of improvement of electronic registers of the health care system of Ukraine]. Available from: https://niss.gov.ua/sites/default/ files/2020-11/electronni-reestry.pdf [reviewed 2020.08.20] (Ua).

14. Nakaz Ministerstva okhorony zdorovia Ukrainy vid 19.10.2015 №681. Pro zatverdzhennia normatyvnykh dokumentiv shchodo zastosuvannia telemedytsyny u sferi okhorony zdorovia [Order of the Ministry of Health dated 19.10.2015 № 681. On approval of regulations on the use of telemedicine in health care]. Available from: https://zakon.rada.gov. ua/laws/show/z1400-15\#Text [reviewed 2020.08.20] (Ua).

\section{ORCID and contributionship:}

Oleksandra Rudnyeva: 0000-0003-1190-2352 ${ }^{A, D, F}$

Olena Prykhodko: 0000-0002-5748-9009 A, B, D, E

\section{Conflict of interest:}

The Authors declare no conflict of interest

\section{CORRESPONDING AUTHOR Oleksandra Rudnyeva \\ SRI SBLG NALSU \\ tel: +380675746994 \\ e-mail:rudoleksa@gmail.com}

Received: 30.08 .2020

Accepted: 30.11 .2020

\footnotetext{
A - Work concept and design, B - Data collection and analysis, C - Responsibility for statistical analysis, D-Writing the article, $\mathbf{E}$-Critical review, $\mathbf{F}$ - Final approval of the article
} 